\title{
The basis of children's trust towards their parents in Java, ngemong: Indigenous psychological analysis
}

\author{
Hakim, Mochammad Abdul \\ Center for Indigenous \& Cultural Psychology, Faculty of Psychology, Universitas Gadjah Mada, \\ Yogyakarta, Indonesia (hakimpsi@yahoo.com) \\ Thontowi, Haidar Buldan \\ Center for Indigenous \& Cultural Psychology, Faculty of Psychology, Universitas Gadjah Mada, \\ Yogyakarta, Indonesia (haidar.buldan@gmail.com) \\ Yuniarti, Kwartarini Wahyu \\ Center for Indigenous \& Cultural Psychology, Faculty of Psychology, Universitas Gadjah Mada, \\ Yogyakarta, Indonesia (kwartarini_yuniarti@yahoo.com) \\ Kim, Uichol \\ College of Business Administration, Inha University, Incheon, Korea (uicholk@yahoo.com)
}

Received: 10 November $2011 \quad$ Revised: 15 December $2011 \quad$ Accepted: 5 January 2012

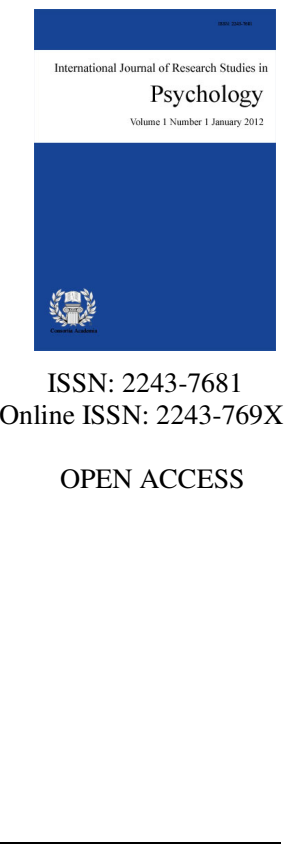

\section{Abstract}

The word among is used to describe the parent-child relationship in Javanese cultural context. Javanese is one of ethnic groups in Indonesia. According to Dewantara (1968), among consists of three nurturing components: providing affection (asih), stimulating potentials of the child (asah), and fulfilling the needs of the child (asuh). The purpose of this study was to examine the relationship between the concept of among and the development of trust towards parents. This study examines the reasons why Javanese trust their mothers and fathers. A total number of 356 Javanese students (males $=97$, females $=259$ ) at Universitas Gadjah Mada completed open-ended questionnaires, asking how much they trust their parents, and the reasons why they trust their parents. The data was analyzed using indigenous psychological approach. Preliminary coding, categorization, axial coding and cross-tabulations were run accordingly. Results show as the following: first, the students tend to trust their mothers more than their fathers. Second, trust to mothers was more on the direction of emotional bonds, whereas trust to fathers was more related to the cultural expectations. The three components of among (asih, asah, and asuh) were also found in the results of the study and appeared to be frequently stated in the responses. The study concluded that Javanese children's trust to mother tends to base on affectional (asih) and caring (asuh) aspects, while their trust to fathers laid on teaching and modeling (asuh) aspects. Many psychologists believe that the characteristics of children's general trust which is growing in the family context become the basis of social relation in the social interaction. It is good to know that, so parents will also have to learn the expection of their children to facilitate them growing, and eventually leading to their fruitful accomplishments of the children. Parental education in forming the basic trust for facilitating the children's growth in the local context is something we might need to 
Hakim, M. A., Thontowi, H. B., Yuniarti, K. W., \& Kim, U.

develop and construct in the future. In the long future these will contribute, to the reduction of any conflicts and social friction, which (was suspected) originated from the lack of trust between social groups. A strong foundation of trust is eventually strenthening the establishment of harmonious society under the frame of Unity in Diversity (Bhinneka Tunggal $I k a)$, the basis of Indonesian nationalism.

Keywords: Ngemong; among; trust; parents-child relation; Javanese family; indigenous psychology; Indonesia 


\section{The basis of children's trust towards their parents in Java, ngemong: Indigenous psychological analysis}

\section{Introduction}

Trust plays a fundamental role to build social relations in extremely diverse societies as Indonesia. Numerous conflicts and social friction emerge due to differences in ethnicity, religion, and race which actually originated from the lack of trust between social groups. Trust plays a vital component in establishing harmonious society under the frame of Unity in Diversity (Bhinneka Tunggal Ika) which becomes the basis of Indonesian nationalism (Sadli, 2004). According to Ki Hadjar Dewantara (1889-1959), the father of Indonesian modern education, the family serves as the initial social unit that becomes a basis for the actualization of a harmonious society and nation. These reasons confirm the significance of studying the formation of trust in the family context.

Studies on trust are commonly approached using experiments or surveys, whereas the definitions of trust have been conceptualized by the researchers in advance (Kuwabara, Willer, Macy, Mashima, Terai, \& Yamagishi, 2007; Reekens \& Hooghe, 2008; Miller \& Mitamura, 2003; Glanville \& Paxton, 2007; Delhey \& Newton, 2003). These particular research models on trust are vulnerable to over generalizing conclusions (Hardin, 2001). Experiments are performed in specific contexts and they assume that all issues are identical in all contexts. Variety in culture and interpretations of trust are ignored (Choi \& Kim, 2002). Choi and Kim proposed that we need to define in an indigenous context, in accordance with how the members of a particular community use and interprets trust.

\section{Literature review}

\subsection{The definition of Trust}

Debates continue to proceed among social scientists on the meaning of trust as well as its relationship with other similar concepts. Researchers distinguish between trust and trustworthiness (Kiyonari, Yamagishi, \& Cook, 2001; Yamagishi, 1998; Yamagishi, Kikuchi, \& Kosugi, 1999; and Yamagishi, Kanazawa, Mashima, \& Terai, 2005), as well as trust with assurance and confidence (Yamagishi, 1998). Trust and trustworthiness are two similar constructs, resembling two faces of the same coin (Yamagishi, 1998), and as a consequence occasionally result in definitional incoherence between the two constructs (Cook, Hardin, \& Levi, 2005; Hardin, 2002). Trust refers to the degree to which a person trusts another person; meanwhile trustworthiness refers to the characteristics or a person's capacity to trust.

Yamagishi (1998) further elaborates on the differences between general trust with assurance and confidence. Assurance implies that the individual has the expectations towards others because he/she has already established fine relations with a person. Meanwhile, expectations towards others based on the ability for that person to fulfill that expectation is referred to as confidence. Upon this relationship, the actor who trust does not possess the risk of betrayal, meanwhile the primary characteristic of trust is the risk of a trustee to be betrayed when investing his/her trust to someone else (Yamagishi, 1998; Wicks, Berman, \& Jones, 1999).

Differences among researchers upon the definition of trust remain the evidence. In a number of his experimental studies, Yamagishi (2008) formulated trust as the presumption that a person does not place negative intentions towards him/herself. This is what is referred to as general trust. To trust another person, Yamagishi explains, indicates an individual's confidence, based on heightened sensitivity and skills to differentiate between those perceived to be trustworthy and untrustworthy, while remaining to hold the assumption that basically all 
people are trustworthy until evidence is found to perceive the individual as untrustworthy (Yamagishi, 2008). Hardin (2006) proposed a critic towards the concept, arguing that general trust merely applies in traditional societies where morals are strictly obeyed by each community member. Custom morals ensure social assurance so that individuals need not to feel worried of being betrayed by others.

Hardin $(2004 ; 2006)$ understands trust as the encapsulated interest where a person's trust towards others depends on the assessment towards their motivation. Trust serves as a cognitive variable (Hardin, 2004), as a form of relationship towards 3 components, including I as the one who convey the trust, them as the trustee, and the object of trust (Hardin, 2002). When a person states "I trust you", this does not necessarily imply that the individual trust all matters upon them; however the trust merely covers specific matters. We trust doctors about medicine for a particular disease however not so for political news. Therefore, a person's capacity concerning an object of trust becomes vital as a basis for trust.

\subsection{Trust in Javanese Philosophy}

Indonesia is recorded as the fourth largest populated country in the world with a population of more than 222 millions people. Indonesia is inhabited by 313 ethnic groups with different languages and inhabits 10.000 large and small islands. Islam is the religion of the majority followed by $90 \%$ of Indonesians. However, the government officially acknowledges five other official religions, namely: Christianity, Catholic, Hindu, Buddha, and Confucianism. Such rich social and cultural diversity serves as one of Indonesia's pride towards its nation.

Such diversity in Indonesia also poses a challenge in conducting indigenous psychology research. Several ethnic groups have for centuries lived geographically separated and developed their own cultures. Only a few have the ability to travel and interact with ethnic groups from other islands. A number of past anthropologists who also intended to study Indonesia had encountered similar problems. Researchers, for example Clifford Geertz, Niels Mulder, and Hildred Geertz have strategically chosen one ethnic group with the largest population, namely the Javanese. Panggabean (2004) chose to conduct a similar strategy for a number of reasons. First, Javanese cultures have extended influence in the country. Javanese influence is particularly evidence from work contexts, particularly in the public sector. Second, thought and behavioral patterns of Javanese culture are also apparent in other cultures. Third, the Javanese culture constitutes the Indonesian culture with the largest exploration by researchers.

In the Javanese Dictionary, published by the Balai Bahasa Yogyakarta (The Language Board of Yogyakarta) (2001), the word andel corresponds to the meaning of trust. Andel refers to a person or object that may be trusted in accomplishing a particular occupation or task. Ngandel refers to andel when pronounced as a verb and refers to the acknowledgement that something truly exists. Another word holding similar notions as andel, is yakin. Yakin implies (1) strong belief, (2) certain; clear; and (3) profoundly knowledgeable. There lies a difference in using the word andel and yakin. Andel implies that a person trusts something without entailing personal experience towards the object of trust. The trust is rather developed through a trustworthy mediator. On the other hand, yakin requires an individual to experience the event him/herself and discover the exact truth. However, it is the concept of ngandel which is more commonly used in the Javanese social life.

According to the teachings of Dewantara, ngandel itself serves as one of the components in a hierarchical series of words namely; ngandel (trust), kandel (firm stance), kendel (brave), and bandel (not easily afraid). The series of words resemble a distinct characteristic within each level, starting from the word considered as most profane to the most transcendental. The series implies that a person acquiring trust (ngandel) will develop a firm stance (kandel). How is this possible? Javanese people believe that a firm stance may only be achieved only if that person hold a principle of which acknowledged to be true. Therefore when a person acquires a firm stance, thus he would develop the courage to perform the acts his believes is true (kandel). In the Javanese tradition, trust constitutes the basic attitude of an individual to deal with real-life challenges, face uncertainty, and the risks that emerge during his course of life. 
The basis of children's trust towards their parents in Java, ngemong: Indigenous psychological analysis

By trusting other people, Javanese try to reduce the possibilities which may threaten social harmony. As a result, several Javanese teachings contain morals to abandon acts of negatively judging a person (syak wasangka), and rather than that it encourages people to positively judge other people as much as possible. Of course these teachings are not always practiced in a social life context. However, the effects are evidence in international surveys of trust conducted by Kim (2009), demonstrated that trust levels of Javanese to strangers is slightly higher compared to Koreans and almost equivalent to the levels of Danish communities. In a conceptual sense, the end point of a Javanese person's trust is tawakal (Dewantara, 1935), implying the absence of fear as a result of the belief that the self is under God's control.

\subsection{The Concept of Ngemong}

In East Asia, bonds between a person and other people constitute the basic component in establishing social structure (Choi \& Kim, 2006; Yang, 2006). For example, Hwang (2006) and Yang (2006) mentioned that in Chinese culture, the concept of guanxi (relationship) is deemed central to explain social interactions in the contexts of families, schools, work places and communities. In Japan, amae becomes the key component in establishing interpersonal relations (Yamaguchi \& Ariizumi, 2006). Whilst in Korea, attachment and affection (concept of Jung) becomes an element of bonding for the family, friends, and colleagues (Choi et al, 2006). Researchers in East Asia are in agreement to the notion that Confucian values remain as a strong influence of social characteristics in East Asia (Megawangi, et al, 1995). Confucianism values are evidence in families and traditions by placing family harmony as the foundation in establishing community harmony. Up to the present, Confucianism interaction patterns apparent in Japanese and Korean communities include orientation to groups, acceptance of authority, mutual dependence, avoidance of conflict, awareness to seniority, and compliance (Rozman, 1991).

Similar to the East Asian community patterns described above, awareness to seniority remains strong in the Javanese community. Most distinctive of this can be observed in the way that Javanese treat people that are divers according their age groups and social status. By being older, this does not necessarily mean older in age, but also in social status, familial status, and status in an employment context. This particular hierarchical structure is apparent from practices of giving additional verbal expressions to the people who are older, for instance mas (for older men), mbak (for older women), Bapak (for men who are much older), and Ibu (for females who are much older). These labels are basically valid in the familial context however it is widely used in other social contexts for example in school and the work place. These examples are not separated from Javanese orientations in trying to expand the familial atmosphere to the community level (Dewantara, 1935b). According to the understanding of Javanese, the hierarchical seniority, as explained above, places considerable social responsibility to the people that are older. People, who are considered to be senior, are obliged to practice ngemong to those younger.

The concept of ngemong originates from the family context. According to the Javanese Dictionary, published by the Balai Bahasa Yogyakarta (2001), ngemong (in the verbal form) or among (nominal form) refers to taking care of, guide, and educate a child with full affection. Dewantara, interpreted the concepts of ngemong or among into the three principles of child nurturance, namely; asih, asah, and asuh. Asih implies sincerely taking care of and with full affection. Moreover, it implies habitual transformation or creating habits of good deeds along with prayers that the love and affection will result in a decent child who upholds moral excellence. Asah refers to providing examples of good and bad, without depriving the child's rights to grow and develop freely in line with their natural character. While Asuh implies the process of observing, nurturing and taking care of the child, to ensure they are able to develop themselves, become responsible, and discipline based on their ethical values. In other words it may be concluded that the concept of among serves three simultaneous functions, namely; caring, modeling and monitoring.

These three functions constitute the obligations of parents towards their children. In the context of the family, the father and mother become the main actors of ngemong (referred to as pamong). This position is particularly 
important, as in the Javanese community, families become initial settings for education in shaping good manners or building the child's character (Dewantara, 1935a; Dewantara, 1958). It is also within the family context that a child internalizes the basis of trust to other people, especially trust to both parents.

Within the Javanese context, the mother (on Javanese referred to as $i b u$ ) gains a highly respected status. The mother is described as the figure that nurtures as well as becomes the source of one's life. This term ibu later broadened its meaning to include all things that have characteristics of protection and source of life. Javanese refer to their country as Ibu Pertiwi or the Motherland literally translated, not the Fatherland. Capital cities are referred to as ibu kota. One prominent Islamic teaching, strongly held by Javanese, is that heaven lies beneath the mother's feet. On the other hand, paternalistic patterns in Javanese communities place women as second class citizens. This implies a unique position, whereas they gain high respects as a mother, but are regarded second class as a woman.

The primary roles of the mother in traditional Javanese communities are to nurture the children and manage domestic affairs (Geertz, 1961). Nevertheless, they also have roles to assist the husband in managing the family rice field. Family patterns in modern Javanese communities contrast with the traditional patterns. Several mothers pursue careers as done by men. These women no longer spend most of their time at home. Less frequent mother-child interactions occur compared to traditional families. Although these shifts in patterns are evidence, however they do not erase traditional Javanese cultural norms. Child rearing remains to be viewed as the primary roles of the mother, even in modern Javanese communities.

A number of previous studies demonstrated the significant influence of parents towards their children in Java. In her research report, Indrayanti (2007) stated that intensity of communication between undergraduate students with their parents significantly increases the students self confidence. The degree of the parents' influence towards their children in Java cannot be separated from the strength of the emotional bond between both parties that has been established for a long time. It is not uncommon for Javanese children to stay and remain living with their parents longer compared to the Western people (Monk, Knoers, \& Haditono, 2001). Children generally start to separate from their parents when they married (Megawangi, et al., 1995).

Strong emotional bond between parent-child cannot be separated from the styles of parenting. Zevalkink and Riksen-Walvaren (2001) identify two features of parenting which are most apparent of Javanese. First, parents rarely give physical punishment (slap or batter) to their children. They are generally permissive. To enforce discipline towards their children, they are more likely to make their children scared, yell at, and embarrass them in front of other, or make cynical remarks towards them in an implicit way. The second feature is that Javanese parents relatively spoil the desires and needs of their children before weaning them and tend not to pay too much attention to the demands of the child after weaning at three years of age. With regard to the importance of basic trust building, and the fact that there is no evidence studying on the basic trus construction, this study aimed to explore and learn the relationship between the concept of among and the development of trust towards parents. In addition to that, this study aimed also to know the reasons why Javanese trust their mothers and fathers.

\section{Method}

\subsection{Study participants}

The study participants were undergraduate students of a state university who claimed themselves as having Javanese ethnicity. A total number of 361 students participated consisting of 97 males and 264 females. From the mothers' work status, 113 students reported that their mothers were housewives have a status as a housewife and 248 students stated that their mothers work. 


\subsection{Measures}

The instrument used to collect data consists of 2 closed-ended questions and 2 open-ended questions. The two questions include "How much do you trust your Mother?" and "How much do you trust your Father?" The quantitative data was analyzed using descriptive statistics to compare the degree of trust between respondent groups.

Qualitative data analysis was conducted following the steps as explained by Hayes (2000), namely; (a) prepare data for analysis, (b) identify specific information on the items that seem relevant to the topic of the study, (c) sort the data based on emerging themes, (d) examine the themes and formulate a definition, (e) re-examine the themes that are formed and then match them with the data, (f) use all material related to the theme to make a construct, of which eventually contains the category name and the definition of the supporting data, and $(\mathrm{g})$ choose the data which is relevant to make it as an illustration to describe each theme. A group of which consists of a minimum of 3 post-graduate students perform categorization together to ascertain inter-rater reliability of the categories. Ambiguous answers were discussed; if they did not suit the established categories then they are put in the category of others. The categorized responses were then cross-tabulated with the information of mothers' work status of the respondents.

\section{Results}

Thematic analysis of reasons why the respondents trust their mothers result in six large categories encompassing 17 smaller categories within them. The results of the analysis are presented in Table 1 . Six of the large categories include emotional relationship, role of relationship, support, reliability, honesty, and good characters. Results are presented in the frame of mother-child or father-child or parents-child relationship, and the word of "child or children" refers to the study participants who are students at the time of the study conducted.

Emotional relationship constitutes the most dominant response (27\%). Emotional relationship between child and mother is built on feelings of closeness, child's love to mother, mother understands the child, fine child-mother communication, and because the child loves the mother. Typical responses for the emotional relationship category include: I trust my mother very much because she is the closest person to me, who cares about my life, so whatever it is that my mother expects, it is for the best and I trust my mother because sometimes, believe it or not, we have an emotional bonding like other mother-children relationships. So, what my mother says sometimes could actually happen and be proved, so I trust her.

The category with the second highest proportion is role of relationship (20.8\%). Role of relationship that is established between mother and child is based on blood ties or consanguinity, role of relationship, nurturing, and important in my life. The following includes a respondent's response describing the role relationship role: I trust her because if it was not for my mother I would not have been born. Because she is my mother and knows what kind of person I am.

Furthermore, the degree of how reliable a mother is to be trusted seems to influence the child's trust. The child is certain that the mother would never mislead the child to negative ways. Mother is also regarded to acquire the internal capacity to be trusted and has provided proof of her promises. Responses indicating reliability include: So far what she says is always right, and I know and realize that she has greater life experiences than myself. That's why she understands so much.

The factor of support from mother also plays a role of forming a child's trust. The mother will gain a child's trust when the child perceives that the mother has given the best to them, given guidance, and expects the best for the child. Responses indicating a mother's support to the child include: "Because mother can support and comfort me and because my mother has given advice about anything that we do". 
Hakim, M. A., Thontowi, H. B., Yuniarti, K. W., \& Kim, U.

\section{Table 1}

Why do trust your mother?

\begin{tabular}{|c|c|c|c|c|c|c|}
\hline \multirow{2}{*}{$\begin{array}{l}\text { Categorization } \\
\text { 1. Emotional Relationship }\end{array}$} & \multicolumn{2}{|c|}{ Not employed } & \multicolumn{2}{|c|}{ Employed } & \multicolumn{2}{|c|}{ Total } \\
\hline & 31 & $(27.4)$ & 66 & $(26.6)$ & 97 & $(27.2)$ \\
\hline Feeling close & 12 & $(10.6)$ & 18 & $(7.3)$ & 30 & $(8.4)$ \\
\hline Love me & 9 & (8) & 16 & $(6.5)$ & 25 & $(7.0)$ \\
\hline Understand & 7 & $(6.2)$ & 15 & (6) & 22 & $(6.2)$ \\
\hline Good communication & 2 & $(1.8)$ & 8 & $(3.2)$ & 10 & $(2.8)$ \\
\hline Love her & 1 & $(0.9)$ & 5 & (2) & 6 & $(1.7)$ \\
\hline 2. Role of relationship & 29 & $(25.7)$ & 45 & $(18.1)$ & 74 & $(20.8)$ \\
\hline Consanguinity & 10 & $(8.8)$ & 23 & $(9.3)$ & 33 & $(9.3)$ \\
\hline Role of relationship & 9 & (8) & 10 & (4) & 19 & $(5.3)$ \\
\hline Nurturing & 9 & (8) & 9 & $(3.6)$ & 18 & $(5.1)$ \\
\hline Important in my life & 1 & $(0.9)$ & 3 & $(1.2)$ & 4 & $(1.1)$ \\
\hline 3. Reliability & 17 & $(15.1)$ & 45 & $(18.2)$ & 62 & (17.4) \\
\hline Will not lead astray & 9 & (8) & 16 & $(6.5)$ & 25 & $(7.0)$ \\
\hline Reliable & 2 & $(1.8)$ & 13 & $(5.2)$ & 15 & $(4.2)$ \\
\hline Proven & 6 & $(5.3)$ & 16 & $(6.5)$ & 22 & $(6.2)$ \\
\hline 4. Support & 22 & $(19.4)$ & 39 & $(15.7)$ & 61 & $(17.1)$ \\
\hline Give me the best & 12 & $(10.6)$ & 26 & $(10.5)$ & 38 & (10.7) \\
\hline Guidance & 4 & $(3.5)$ & 8 & $(3.2)$ & 12 & $(3.4)$ \\
\hline Wish the best & 6 & $(5.3)$ & 5 & (2) & 11 & $(3.1)$ \\
\hline 5. Honesty & 6 & $(5.3)$ & 21 & $(8.5)$ & 27 & $(7.6)$ \\
\hline 6. Good characters & 6 & $(5.4)$ & 24 & $(9.6)$ & 30 & $(8.4)$ \\
\hline Good characters & 6 & $(5.4)$ & 24 & $(9.6)$ & 30 & $(8.4)$ \\
\hline 7. Others & 2 & $(1.8)$ & 3 & $(1.2)$ & 5 & $(1.4)$ \\
\hline Total & 113 & $(100)$ & 243 & $(100)$ & 356 & (100) \\
\hline
\end{tabular}

Two of the other factors that play part in forming a child's trust to mother include good characters $(8.4 \%)$ and honesty (7.6\%). An example of honesty as expressed by a respondent: Because I'm sure my mother will never lie to me. Except there's something that she must keep as a secret and when I ask her what happened, she looks kind of 'different'. Two of the responses below indicate mother's good characters: Because since I was a child my parents are my role models and I need to.

What about the basis of a child's trust towards his father? The results of the categorization as presented in Table 2 demonstrate that six categories emerge which consist of 26 smaller categories. Support becomes a factor of trust to father that is most frequently stated by the respondents $(26 \%)$. They regard that their father has given the best to their children. Father gives lots of advice, responsibility, always expects the best, and works hard to fulfill the needs of his child. A number of reasons categorized under support include: My father always does the best thing for me definitely and I trust my father because he has taught me, he always educates me a positive thing.

The second largest factor of children trusts their fathers is role of relationship, which is culturally bounded. Trust relationship was formed from the status and roles in the family performed by the father comprise of the tasks of a father culturally, blood ties, child rearing, and father as the head of the household. Responses indicating role of relationship include: Because he take care of me and raised me and because he made me born, made me growth, and gives his advices for the best I am. 
The basis of children's trust towards their parents in Java, ngemong: Indigenous psychological analysis

Table 2

Why do you trust your father?

\begin{tabular}{|c|c|c|c|c|c|c|}
\hline \multirow{2}{*}{$\frac{\text { Categorization }}{\text { 1. Support }}$} & \multicolumn{2}{|c|}{ Not employed } & \multicolumn{2}{|c|}{ Employed } & \multicolumn{2}{|c|}{ Total } \\
\hline & 30 & $(26.55)$ & 64 & $(25.40)$ & 94 & $(25.75)$ \\
\hline Give me the best & 9 & $(7.96)$ & 20 & $(7.94)$ & 29 & $(7.95)$ \\
\hline Guidance & 6 & $(5.31)$ & 12 & $(4.76)$ & 18 & $(4.93)$ \\
\hline Responsible & 7 & (6.19) & 8 & $(3.17)$ & 15 & $(4.11)$ \\
\hline Wish the best & 5 & $(4.42)$ & 10 & $(3.97)$ & 15 & $(4.11)$ \\
\hline Support & - & - & 10 & $(3.97)$ & 10 & $(2.74)$ \\
\hline Hard-working & 3 & (2.65) & 4 & $(1.59)$ & 7 & (1.92) \\
\hline 2. Role of relationship & 20 & $(17.70)$ & 38 & $(15.08)$ & 58 & (15.89) \\
\hline Role of relationship & 9 & (7.96) & 13 & $(5.16)$ & 22 & $(6.03)$ \\
\hline Consanguinity & 4 & $(3.54)$ & 5 & (1.98) & 9 & $(2.47)$ \\
\hline Nurturing & 4 & $(3.54)$ & 8 & $(3.17)$ & 12 & (3.29) \\
\hline Head of the household & 3 & $(2.65)$ & 12 & $(4.76)$ & 15 & $(4.11)$ \\
\hline 3. Reliability & 12 & $(10.62)$ & 41 & $(16.27)$ & 53 & $(14.52)$ \\
\hline Reliable & 7 & 6.19 & 24 & $(9.52)$ & 31 & (8.49) \\
\hline Proven & 4 & $(3.54)$ & 9 & $(3.57)$ & 13 & (3.56) \\
\hline Will not lead astray & 3 & $(2.65)$ & 15 & $(5.95)$ & 18 & $(4.93)$ \\
\hline 4. Emotional relationship & 20 & $(17.70)$ & 30 & $(11.90)$ & 50 & $(13.70)$ \\
\hline Feeling close & 5 & $(4.42)$ & 9 & $(3.57)$ & 14 & $(3.84)$ \\
\hline Love me & 6 & $(5.31)$ & 6 & $(2.38)$ & 12 & $(3.29)$ \\
\hline Mutual trust & 6 & $(5.31)$ & 6 & $(2.38)$ & 12 & (3.29) \\
\hline Good communication & 3 & $(2.65)$ & 9 & $(3.57)$ & 12 & $(3.29)$ \\
\hline 5. Good characters & 15 & $(13.27)$ & 36 & $(14.29)$ & 51 & (13.97) \\
\hline Wise & 6 & $(5.31)$ & 13 & $(5.16)$ & 19 & $(5.21)$ \\
\hline Kind-hearted & 3 & $(2.65)$ & 10 & $(3.97)$ & 13 & $(3.56)$ \\
\hline Experience & 2 & (1.77) & 8 & $(3.17)$ & 10 & $(2.74)$ \\
\hline Model & 4 & (3.54) & 5 & (1.98) & 9 & $(2.47)$ \\
\hline 6. Honesty & 5 & $(4.42)$ & 18 & $(7.14)$ & 23 & $(6.30)$ \\
\hline 7. Others & 10 & $(8.85)$ & 21 & $(8.33)$ & 31 & $(8.49)$ \\
\hline Others & 4 & (3.54) & 7 & $(2.78)$ & 11 & $(3.01)$ \\
\hline Irrelevant & 2 & (1.77) & 2 & $(0.79)$ & 4 & $(1.10)$ \\
\hline Blank & 1 & $(0.88)$ & 5 & (1.98) & 6 & $(1.64)$ \\
\hline Clever & 4 & (3.54) & 1 & $(0.40)$ & 5 & $(1.37)$ \\
\hline Similarity & 1 & $(0.88)$ & 2 & $(0.79)$ & 3 & $(0.82)$ \\
\hline Admired & 2 & (1.77) & 1 & $(0.40)$ & 3 & $(0.82)$ \\
\hline Higher level education & - & - & 3 & $(1.19)$ & 3 & $(0.82)$ \\
\hline Democratic & - & - & 2 & $(0.79)$ & 2 & $(0.55)$ \\
\hline Simple & - & - & 2 & $(0.79)$ & 2 & $(0.55)$ \\
\hline Firm & - & - & 1 & $(0.40)$ & 1 & $(0.27)$ \\
\hline Try hard & - & - & 1 & $(0.40)$ & 1 & $(0.27)$ \\
\hline White lies & & & 1 & 0.40 & 1 & 0.27 \\
\hline
\end{tabular}

Fathers' reliability seems to be important for the formation a child's trust to the father. Reliability operationally refers to the degree the father proves what he says to the child. They, the children, were also 
convinced that the father would never mislead their children to negative ways. Father is trusted because he is reliable to solve the problems encountered by the child and is responsible. Responses reflecting reliability include: In daily life, I have had a proof that my father always better than me even he knows much about my traits rather than me myself. An example of responses for honesty include: I trust to my father because he is a wise and honest person.

The fourth factor of the basis of child's trust to father is emotional relationship. Children trust their fathers because they feel a sense of love and closeness to their fathers. Children also perceive the relationship to be characterized by mutual trust between them, the establishment of fine communications, and feels that the father is able to understand them. This factor of emotional relationship becomes a basis for a child's trust to his/ her father, as evidence in the following responses: I am close to my father more rather than to my mother since I was a kid. And it makes his character influenced me strongly and I don't know why I trust him. I have a belief that my father really loves me.

Children also consider their fathers' good characters as a basis for their trust. Children trust their fathers because they are kind. Father is also trusted because of his role as a role model, experienced and smart. Responses reflecting trust based on the father's good characters include: My father he is a good man who always wants me get the best and My father gives a good life model and he teaches honesty.

The sixth factor that influences the formation of a child's trust to father is the father's honesty. Based on experience, the child feels that father always tells the truth. An example of responses for honesty include: I trust to my father because he is a wise and honest people.

Furthermore, the data is explored to discover the variations of the reasons of trust based on the work status of the mother. The data exploration is conducted considering the difference of time and frequency of interaction between mothers with career and without career. Does this difference then result in the variance of characteristics of the trust of the child to the parents? Figure 1 presents the characteristics of the child's trust to mothers who are employed and figure 2 presents trust for mothers without employement status.

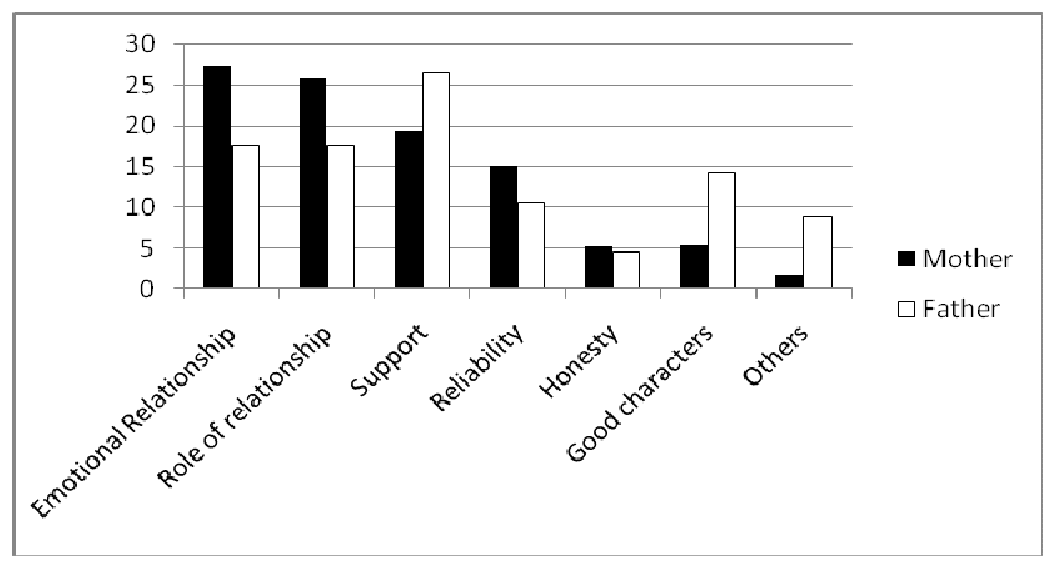

Figure 1. Reasons for a child trusting their parents for the un-working mother group

Observing the two figures above, it is evidence that for the basis of trust for parents, whether for working or non-working mothers, a relatively consistent pattern are identified. Trust to mother is dominant for the factor emotional relationship, role of relationship, and reliability compared to the father. In other hand, trust to father is more dominant for the aspects of support and good characters. Moreover, the child's perception of category honesty for mother and father is not too different. 


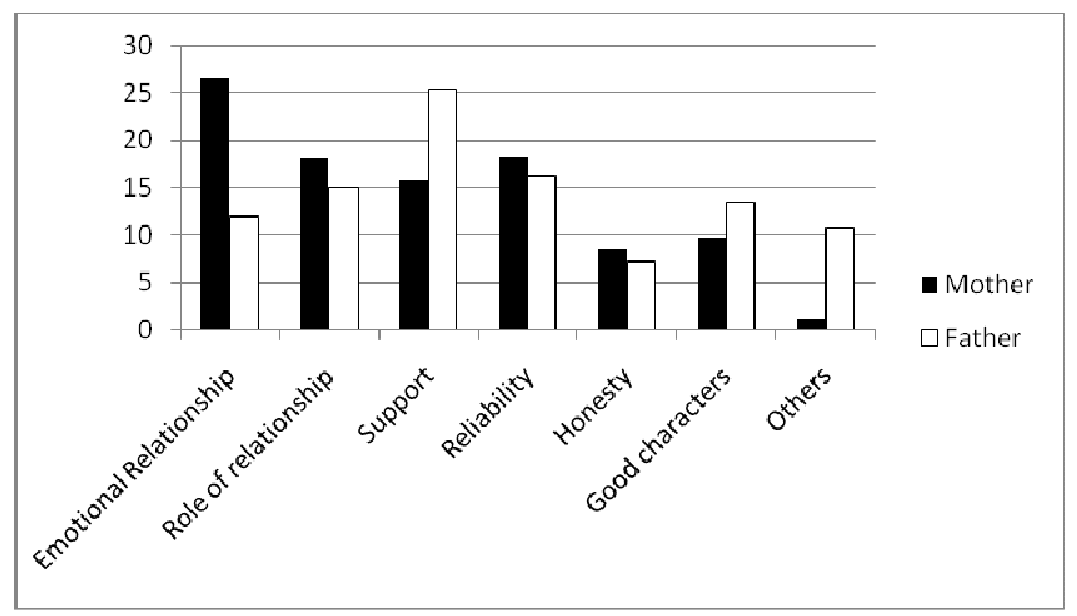

Figure 2. Reasons for a child trusting their parents for the working mother group

\section{Discussion}

The thematic analysis resulted in six factors that become a basis of a child's trust towards fathers and mothers. The six factors include emotional relationship, role of relationship, support, good characters, reliability, and honesty. The first three factors imply a relational characteristic of trust; whilst good characters, reliability, and honesty imply a knowledge-based trust. Yamagishi (1998) provided the term assurance for relational trust and confidence for knowledge-based trust. According to Yamagishi (1998), assurance and confidence distinguishes from general trust. General trust refers to the presumption that other people do not have negative intentions upon them. Therefore trust does not emerge as a consequence of other people's actions towards the person, but rather than that, it refers to the basic attitude of an individual towards their social life.

In contrast, the current study demonstrates that a child's trust is established by the attitudes and behaviors of parents. Behaviors from the mother and father are perceived differently by children. When the study participant was asked: Why do you trust your mother? The largest responses indicating trust to mother included emotional relationship, role of relationship, and support. Meanwhile for the father responses included support, role of relationship, and good characters. Each response category comprised of a number of behaviors that are typical of each parental role. As an example, for the category emotional relationship, behaviors that are typical of a father include faithful to family, never disappoints me, and not interfering. Meanwhile typical behaviors for mothers includes trust me and having inner contact and relationship. The results confirm previous data surveys that demonstrated higher trust levels for mothers compared to fathers. Therefore, it may be concluded that children have stronger trust to figures that provide emotional bonds.

Unlike results of this study, the Javanese concept of ngandel as proposed by Dewantara. Under the concept of ngandel, trust emphasizes on positive attitudes in the social life, similar to general trust as referred to by Yamagishi. In addition to that, ngandel is conceptually based on tawakal, which implies not being afraid to ever be betrayed by others as the individual is certain that they are under God's divine protection. The data show that a Javanese child trust his/ her parents as a consequence of how the parents treat the child.

The reasons for trusting parents is consistent with the concept of ngemong. Ngemong consists of three nurturing components: providing affection (asih), educating and modeling (asah), and fulfilling the needs of the child (asuh) (Dewantara, 1935). The factor of emotional relationship represents asih, factors of good characters, reliability, and honesty is a manifestation of asah, and asuh reflects support and role of relationship. Division of parents' role are complementary in Javanese contexts, the mother holds primary responsibilities in a particular 
matter assisted by the husband, and vice versa. According to ngemong, the father has the primary role in asah, while the mother holds responsibility for the asih and asuh aspects. Consistent with the concept of ngemong, the current study demonstrates that asih and asuh become the dominant responses for the respondents to trust their mothers. In contrast, the aspect of asah becomes more dominant response for trusting fathers when it is compared to mothers.

Nevertheless, in modern Javanese communities, the mother's roles have shifted to include professional activities beyond the household as done by the father. Would this situation influence the patters of a child's trust to their parents? The results of the study demonstrate consistency of the characteristics of a child's trust to parents, whether for employed or non-employed mothers. The findings stress that relational trust established by the family is relatively solid. Values of Javanese culture that emphasize emotional relationship between the children and the parents may become a safeguard for harmony when social changes demand that the mother works outside the home. On the other hand they are still demanded to play the role of the mother of the household. The dilemma faced by Javanese working mothers is the increased responsibility caused by their dual roles in order to maintain family harmony, namely as a career women and also as a mother to her child.

\subsection{Limitations of the study}

This study is by no mean perfect, as an initial exploration study, the data presented in this report has a number of weaknesses. First, the respondents involved in the survey were limited only to undergraduate students. These students are among those selected as the brightest students, therefore the data cannot be representative to describe the responses of Javanese children in general. Second, the proportion of male and female respondents is unequal. This may have influenced the characteristics of the responses delivered in the open-ended questionnaire. In spite of the weaknesses, the study reveals the unique relationship of trust of Javanese children towards their parents. Further studies conducted with a representative sample are required to verify the findings of this study.

\section{Conclusions}

If general trust initially growing in the parent-child relational context, then it is important to understand what are the factors that facilitate the growth of children's trust toward their parents. To what extent, and how, can Javanese children trust towards their parents? In this study, we have compared the level children's trust to mothers and fathers. Moreover, using indigenous psychological analysis we have attempted to explore the basis of Javanese children's trust to both mothers and fathers and integrated the empirical findings into a single local concept of parenting which is called as ngemong. Adopting ngemong as a framework to understand the parent-child relationship in Javanese context, it is understood that Javanese children's trust to mothers tend to base on affection (asih) and caring (asuh) aspects, while their trust to fathers laid on teaching and modeling (asuh) aspects. Many psychologists believe that the characteristics of children's general trust which is growing in the family context become the basis of social relation in the societal level. These findings provide a picture of social characteristics in the Javanese society. Results of the study is very importance because then parents will also have to learn the expections of their children to facilitate them growing, and eventually leading to their fruitful accomplishment of the children. Parental education in forming the basic trust for facilitating the children's growth is something we might need to develop and construct in the future. In the long future these will contribute, highly expected, to the reduction of the current numerous conflicts and social friction, which emerged due to differences in ethnicity, religion, and race which (was suspected) originated from the lack of trust between social groups. The strong foundation of trust eventually will be strenthening the establishment of harmonious society under the frame of Unity in Diversity (Bhinneka Tunggal Ika), the basis of Indonesian nationalism.

Note: The article was presented in the 8th Biennials Conference of Asian Association of Social Psychology at New Delhi, India on December 2009. 


\section{References:}

Balai Bahasa Yogyakarta [The Language Board of Yogyakarta]. (2000). Kamus Bahasa Jawa [Javanese Dictionary]. Yogyakarta: Kanisius.

Choi, S. C., \& Kim, K. (2006). Naive psychology of Koreans' interpersonal mind and behavior in close relationships. In U. Kim, K. S. Yang, \& K. K. Hwang (Eds.), Indigenous and cultural psychology: Understanding people in context (pp. 357-369). New York: Springer.

Choi, S. C., \& Kim, U. (2004). Emotional attachment as the basis of trust and interpersonal relationships: Psychological, indigenous and cultural analysis. In B. N. Setiadi, A. Supratiknya, W. J. Lonner, \& Y. H. Poortinga (Eds.). Ongoing themes in psychology and culture (Online Ed.). Melbourne, FL: International Association for Cross-Cultural Psychology. Retrieved from http://www.iaccp.org

Cook, K. (2001) Trust in society. In K. Cook (Ed.). Trust in society (pp. xi-xii). New York: Russel Sage Foundation.

Cook,K., Hardin, R., \& Levi, M. (2005). Cooperation without trust? New York: Russel Sage Foundation.

Delhey, J., \& Newton, K. (2003). Who trusts? The origins of social trust in seven societies. European Societies, 5, 93-137. <http://dx.doi.org/10.1080/1461669032000072256>

Dewantara, K. H. (1935a). Keluarga sebagai pusat pendidikan [Family as a center of education]. Warsita, May, $1(3)$.

Dewantara, K. H. (1935b). Sistim Trisentra [The Trisentra system]. Warsita, June, 1(4).

Dewantara, K. H. (1958). Hidup keluarga sebagai sendi persatuan [Family life as the basis of national integration]. Pusaka, July, 20(4).

Glanville, J. L., \& Paxton, P. (2007). How do we learn to trust? A confirmatory tetrad analysis of the sources of generalized trust. Social Psychology Quarterly, 70, 230-242. $<$ http://dx.doi.org/10.1177/019027250707000303>

Hardin, R. (2001).Conceptions and explanations of trust. In Cook, K., (Ed.) Trust in society (pp. 3-39). New York: Russel Sage Foundation.

Hardin, R. (2002).Trust and trustworthy. New York: Russel Sage Foundation.

Hardin, R. (2004). Distrust: Manifestations and management. In R. Hardin (Ed.) Distrust. (pp. 3-33). New York: Russel Sage Foundation.

Hardin, R. (2006). Trust. New York: Russel Sage Foundation.

Hayes, N. (2000). Doing Qualitative Analysis in Psychology. New york: Psychology Publisher.

Hwang, K. K. (2006). Constructive realism and Confucian relationalism: An epistemological strategy for the development of indigenous psychology. In U. Kim, K. S. Yang, \& K. K. Hwang (Eds.), Indigenous and cultural psychology: Understanding people in context (pp. 49-72). New York: Springer.

Indrayanti. (2007). Hubungan antara komunikasi orangtua-anak dan kepercayaan diri anak [Relationship between parents-child communication and childs' self esteem]. Unpublished thesis: Gadjah Mada University.

Kim, U., \& Park, Y. (2005). Trust, relationship, and civil society in Scandinavia and East Asia: Psychological, social, and cultural analysis. Korean Journal of Psychological and Social Issues, 11, 133-161.

Kim, U. (2009). Indigenous psychology in cultural context: A new paradigm for research and application. Paper presented in International Conference of Indigenous Psychology, Universitas Gadjah Mada, Yogyakarta, July 11-15.

Kiyonari, T., Yamagishi, T., \& Cook, K. (2006). Does trust beget trustworthiness? Trust and trustworthiness in two games and two cultures: A research note. Social Psychology Quarterly, 69(3), 270-283.

<http://dx.doi.org/10.1177/019027250606900304>

Koentjaraningrat. ( 1985). Javanese culture. Singapore: Oxford University Press.

Kuwabara, K., Willer, R., Macy, M., Mashima, R., Terai, S., \& Yamagishi, T. (2007). Culture, identity, and structure in social exchange: A web-based trust experiment in the U.S. and Japan. Social Psychology Quarterly, 70, 461-479. <http://dx.doi.org/10.1177/019027250707000412>

Megawangi, R., Zeitlin, M.F., \& Colletta, M. D. (1995). The Javanese Family. In M. F. Zeitlin, R. Megawangi, E. 
Hakim, M. A., Thontowi, H. B., Yuniarti, K. W., \& Kim, U.

M. Kramer, N. D. Colletta, E. D. Babatunde, \& D. Garman (Eds.), Strengthening the family:

Implications for international development (pp. 95-141). Tokyo: United Nations University Press.

Miller, A. S, \& Mitamura, T (2003). Are surveys on trust trustworthy? Social Psychology Quarterly 66, 62-70. $<$ http://dx.doi.org/10.2307/3090141>

Mönks, F. J., Knoers, A. M. P., \& Haditono, S. R. (2001). Psikologi perkembangan: Pengantar dan berbagai bagiannya [Developmental Psychology: An introduction and its parts]. Yogyakarta: Gadjah Mada University Press.

Panggabean, H. (2004). Characteristics of Indonesian intercultural sensitivity in multicultural and international work groups. In B. N. Setiadi, A. Supratiknya, W. J. Lonner, \& Y. H. Poortinga (Eds.). Ongoing themes in psychology and culture (Online Ed.). Melbourne, FL: International Association for Cross-Cultural Psychology. Retrieved from http://www.iaccp.org

Reekens, T., \& Hooghe, M. (2008). Cross-cultural measurement equivalence of generalized trust: Evidence from the European social survey (2002 and 2004). Social Indicator Research, 85,515-532.

$<$ http://dx.doi.org/10.1007/s11205-007-9100-z>

Rozman, G. (1991). The East Asian region in comparative perspective. In G. Rozman (Ed.), The East Asian Region: Confucian Heritage and Its Modern Adaptation. Princeton, NJ: Princeton University Press.

Sadli, S. (2004). Women and peacebuilding in a multicultural society. In B. N. Setiadi, A. Supratiknya, W. J. Lonner, \& Y. H. Poortinga (Eds.). Ongoing themes in psychology and culture (Online Ed.). Melbourne, FL: International Association for Cross-Cultural Psychology. Retrieved from http://www.iaccp.org

Wicks, A. C., Berman, S. L., \& Jones, T. (1999). The structure of optimal trust: Moral and strategic implications. The Academy of Management Review, 24(1), 99-116.

Yamagishi, T. (1998). Shinrai no kouzou: kokoro to syakai noshinka gemu [The Structure of Trust: The Evolutionary Games of Mind and Society]. Tokyo: Tokyo University Press.

Yamagishi, T., Kanazawa, S., Mashima, R., \& Terai, S. (2005). Separating trust from cooperation in a dynamic relationship: Prisoner's dilemma with variable dependence. Rationality and Society, 17(3), 275-308. $<$ http://dx.doi.org/10.1177/1043463105055463>

Yamagishi, T., Kikuchi, M., \& Kosugi, M. (1999). Trust, gullibility, and social intelligence. Asian Journal of Social Psychology, 2, 145-161. <http://dx.doi.org/10.1111/1467-839X.00030>

Yamaguchi, S., \& Ariizumi, Y. (2006). Close Interpersonal Relationships among Japanese: Amae as Distinguished from Attachment and Dependence. In U. Kim, K. S. Yang, \& K. K. Hwang (Eds.), Indigenous and cultural psychology: Understanding people in context (pp. 163-174). New York: Springer.

Yang, K. S. (2006). Indigenous personality research: The Chinese case. In U. Kim, K. S. Yang, \& K. K. Hwang (Eds.), Indigenous and cultural psychology: Understanding people in context (pp. 285-314). New York: Springer.

Zevalkink, J.. \& Riksen-Walraven, J. M. (2001) Parenting in Indonesia: Inter-and intracultural differences in mothers' interaction with their young children. International Journal of Behavioral Development, 25(2), 167-175. <http://dx.doi.org/10.1080/01650250042000113> 